\title{
Experimental evidence for selection against hy- brids between two interfertile red oak species
}

\author{
Oliver Gailing ${ }^{1,2, *}$, Ruhua Zhang ${ }^{1,3}$ \\ ${ }^{1}$ School of Forest Resources and Environmental Science, Michigan Technological University, Houghton, MI, 49931-1295, \\ USA \\ ${ }^{2}$ Present address: Forest Genetics and Forest Tree Breeding, Faculty of Forest Sciences, University of Göttingen, 37077 \\ Göttingen, Germany \\ ${ }^{3}$ Linyi University, middle part of Shuangling Road, Linyi City, Shandong Province, 276000 China \\ * Corresponding author: ogailin@gwdg.de
}

\begin{abstract}
Reproductive isolation between related oak species within one taxonomic section is incomplete. Even though pre- and postzygotic isolation mechanisms have been described for interfertile oak species, natural hybridization is common in contact zones between related oaks. The apparent restriction of interspecific hybrids between ecologically divergent species to intermediate environments in contact zones suggests postzygotic isolation via environmental selection against hybrids in parental environments. Overrepresentation of hybrids in seeds as compared to adult trees provides additional indirect evidence for selection against hybrids.

Here, we used genetic assignment analyses in progeny obtained from a sympatric stand of Quercus rubra and Quercus ellipsoidalis, two interfertile species with different adaptations to drought, to characterize the number of hybrids and "pure" species in the non-germinated acorns and in seedlings. The occurrence of $43.6 \% F_{1}$ hybrids and introgressive forms among the non-germinated acorns and their very low frequency in the seedlings ( $9.3 \%$ ) is to our knowledge the first direct evidence for early selection against hybrids in oaks possibly as result of genetic incompatibilities. Additionally, we found a signature of positive selection on EST-SSR PIE200 in Q. rubra which needs further confirmation. These results contribute to our understanding of reproductive isolation and divergence between interfertile oak species with different ecological adaptations.
\end{abstract}

Keywords: oaks, Quercus rubra, Q. ellipsoidalis, reproductive isolation, microsatellites, EST-SSRS

\section{Introduction}

Controlled crosses between oak species of the same taxonomic section revealed cross-fertility for many species pairs, but also partial incompatibility for some crosses (Cottam et al., 1982; Abadie et al., 2012). Postzygotic barriers were found to be less pronounced than prezygotic barriers when pre- and postzygotic isolation traits (e.g. pollen tube growth and seed production) were compared in intra- and interspecific crosses between two interfertile European white oaks, Quercus petraea (Matt.) Liebl. and Quercus robur L. (Abadie et al., 2012). Despite mechanisms of reproductive isolation, natural hybridization between closely related oak species is common in natural populations where interfertile oaks come into close contact (e.g., Curtu et al., 2007; Owusu et al., 2015). While prezygotic isolation was observed in interspecific experimental crosses, for example between Q. petraea and Q. robur (Steinhoff, 1993; Kleinschmit and Kleinschmit, 2000; Abadie et al., 2012; Lepais et al., 2013), incompatibility was comparatively low between $F_{1}$ hybrids and either of the two parental species (Olrik and Kjaer, 2007). Similar results were found for seeds from $F_{1}$ hybrids between two Californian white oaks, Quercus lobata Née and Quercus douglasii Hook. \& Arn., which were fathered by both parental species (Abraham et al., 2011). Also, selection against hybrids has been proposed as a potential postzygotic isolation mechanism to explain the maintenance of species integrity in oaks despite interspecific gene flow (Lexer et al., 2006). Indeed, hybrids in natural populations are not randomly distributed but are restricted to intermediate environments suggesting postzygotic environmental selection against hybrids in parental environments (Curtu et al., 2007; De Heredia et al., 2009; 
Owusu et al., 2015; Khodwekar and Gailing, 2017). Also, gene flow analyses suggested an overrepresentation of hybrids in the seeds as compared to the adult tree generation in agreement with the hypothesis of selection against hybrids from the seed to the adult tree stage (Curtu et al., 2007; Curtu et al., 2009). Finally, a comparison of intra- and interspecific crosses in Q. petraea and Q. robur showed better performance of progeny from intraspecific (natural) crosses for some but not for all viability traits (Abadie et al., 2012). Lower germination rate in interspecific than in open pollinated (intraspecific) progeny suggested early postzygotic selection potentially as result of genetic incompatibilities (Abadie et al., 2012). However, direct evidence for selection against hybrids and introgressive forms, which are derived from backcrosses of $F_{1}$ hybrids with one of the parental species, has not been demonstrated experimentally in the same random sample.

Quercus rubra L. and Q. ellipsoidalis E. J. Hill are two interfertile red oak species (section Lobatae) with different adaptations to drought. Quercus rubra is a mesophytic species and prefers richer soils with a higher organic matter content while Q. ellipsoidalis occurs on very dry sandy outwash plains (Abrams, 1990; Sander, 1990; Abrams, 1992). The species are stratified along a soil water gradient and hybrids and introgressive forms are found in the contact zones between both species on intermediate soil types (Lind-Riehl et al., 2014; Khodwekar and Gailing, 2017). Genetic assignment and gene flow analyses revealed historic and contemporary gene flow between both species where they grow in close proximity (Lind and Gailing, 2013; Lind-Riehl et al., 2014; Zhang et al., 2015; Khodwekar and Gailing, 2017).

To test the hypothesis of early selection against hybrids, we collected seeds in a sympatric stand on the Upper Peninsula of Michigan at the northern distribution limit of both species. Seeds were planted in a greenhouse and the frequency of hybrids and introgressive forms was estimated in non-germinated acorns as well as in seedlings using genetic assignment analysis at microsatellite markers.

\section{Materials and Methods}

\section{Plant Material}

A total of 677 mature acorns were collected in fall of 2014 from 12 seed trees in a sympatric Q. rubra / Q. ellipsoidalis mixed stand in the Baraga Plains region $\left(46^{\circ} 67^{\prime} 67.46^{\prime \prime} \mathrm{N}\right.$, $\left.88^{\circ} 53^{\prime} 49.41^{\prime \prime} \mathrm{W}\right)$ on the Upper Peninsula of Michigan. In this mixed stand, both morphological species occur next to each other on Rubicon sand in about equal proportions in association with Pinus banksiana Lamb. and Acer rubrum L. (Khodwekar and Gailing, 2017). Leaf morphological differences between genetically assigned species were less pronounced and phenotypic intermediate individuals were more frequent in this sympatric stand than in neighbouring "pure" Q. rubra and $Q$. ellipsoidalis stands (Gailing et al., 2018). Seeds were collected from a group of adjacent seed-bearing trees with intermediate phenotypes. Genetic assignment analyses of the seed trees and the single tree progenies, including adult $Q$. rubra and $Q$. ellipsoidalis trees from neighbouring "pure" stands as reference (Lind and Gailing, 2013), suggested the presence of both species and hybrids/introgressive forms among the seed parents (see below, Supplementary Table 1). Seeds were kept at $4^{\circ} \mathrm{C}$ in a refrigerator for about 4 months and then at the end of February, 2015 planted and grown in 0.5 gallon pots (ca. 1.89 liter) filled with Sunshine 1 mix potting soil (Sun Grow Horticulture, Canada, 70-80 \% Canadian Sphagnum peat moss, perlite, dolomite limestone, Gypsum and wetting agent) in a greenhouse at $20^{\circ} \mathrm{C}$. In June 2015 non-germinated acorns and leaves sampled from young seedlings were collected for DNA isolations.

\section{DNA isolation}

Genomic DNA was isolated from leaves $\left(\mathrm{ca} .1 \mathrm{~cm}^{2}\right)$ using the DNeasy96 Plant Kit (Qiagen, Hilden, Germany) and DNA from embryos was isolated with the DNeasy Plant Mini Kit (Qiagen, Hilden, Germany) according to the manufacturer's instructions. DNA quality and quantity was checked using $0.8 \%$ agarose gels stained with GelRed Nucleic Acid stain (Phenix Research Products, Candler, USA). The DNAI-1000-100 ladder was used as size standard (Life Technologies, Carlsbad, California, USA).

\section{Marker analyses}

Out of 23 EST-SSRs adapted for use in Q. rubra and Q. ellipsoidalis populations (Khodwekar and Gailing, 2017), 11 EST-SSRs were selected for further analyses based on reliable amplification in both leaf and embryo samples (Table 1). PCRs were performed in a $15 \mu \mathrm{l}$ mix with $3 \mu \mathrm{l} \mathrm{HOT} \mathrm{FIREPol} \mathrm{Mastermix} \mathrm{(Solis}$ BioDyne, Tartu, Estonia) which contains $10 \mathrm{mM}$ of $\mathrm{MgCl}_{2}, 0.6$ units of HOTFIREpol Taq polymerase, and $2 \mathrm{mM}$ of each dNTP, 2 $\mu \mathrm{l}$ of dye labelled forward primer $(5 \mu \mathrm{M}), 2 \mu$ reverse primer ( 5 $\mu \mathrm{M}), 6 \mu \mathrm{l}$ deionized water and $2 \mu \mathrm{LNA}$ (ca. $2 \mathrm{ng}$ ). PCRs were run in the Peltier Thermal Cycler GeneAmp PCR system 2700. The PCR profile consisted of a denaturation at $94^{\circ} \mathrm{C}$ for $15 \mathrm{~min}$ and 35 cycles at $94^{\circ} \mathrm{C}$ for $45 \mathrm{sec}$, at $\mathrm{T}_{\mathrm{a}}$ (Table 1) for $45 \mathrm{sec}$, at $72^{\circ} \mathrm{C}$ for $45 \mathrm{sec}$ and a final extension at $72^{\circ} \mathrm{C}$ for $20 \mathrm{~min}$. Fragments were separated on a ABI Prism Genetic Analyzer 3730 (Applied Biosystems) together with the internal size standard GeneScanTM LIZ-500 (Applied Biosystems). Fragment sizes and genotypes were determined after careful visual inspection with the program GeneMarker V2.63 (SoftGenetics, State College, Pennsylvannia, USA). 
Table 1

Microsatellite marker information

\begin{tabular}{|c|c|c|c|c|c|c|c|}
\hline Locus & Repeat motif & Forward primer sequence $\left(5^{\prime}-3^{\prime \prime}\right)$ & Reverse primer sequence $\left(5^{\prime}-3^{\prime}\right)$ & $\begin{array}{c}\mathrm{T}_{2} \\
\left(\mathrm{C}^{9}\right)\end{array}$ & $\begin{array}{c}\text { Size } \\
\text { range } \\
\text { (in base } \\
\text { pairs) }\end{array}$ & $\begin{array}{c}\text { Linkage } \\
\text { group }\end{array}$ & Functional annotation \\
\hline FRR013 & $(\mathrm{CAG})_{5}$ & $\begin{array}{l}\text { 6-FAM- } \\
\text { CGGGGAGTTGATGAGTATT }\end{array}$ & AACACTGTCACCCCCATAGC & 56 & 133-144 & 2 & constans-1 \\
\hline FIR030 & $(\mathrm{AG})_{7}$ & $\begin{array}{l}\text { 6-FAM- } \\
\text { GGaCATATTATCTAGGAGACGA } \\
\text { GGT }\end{array}$ & ATGTCCCATAGCACAGAGCA & 57 & $157-183$ & 7 & nadh dehydrogenase \\
\hline FR0 35 & $(\mathrm{AT})_{6}$ & NED-GCTAAGGTTCGGTGTTCCAA & GGCCAGCAACTAAACCAAGA & 56 & 146-152 & 5 & chaperone protein dnaj \\
\hline FR053 & (GTG) & NED-AGTTTCCCACATTTGTTGC & TACCATGCACCAAGCAATTC & 59 & $136-150$ & 5 & glutaredoxin c9 \\
\hline FRR104 & $(\mathrm{GGT})$ & VIC-TTAACTCGGTTTGCGACTCA & AGCACGTGACTCGACCTGTA & 59 & $203-224$ & 11 & $\begin{array}{l}\text { t2rb--myb branscription } \\
\text { factor }\end{array}$ \\
\hline PIE040 & $(\mathrm{TTC})_{\mathrm{s}}$ & $\begin{array}{l}\text { NED. } \\
\text { GTGAGAGAGGGAGAGACAAAGA } \\
\text { AGAAAAA }\end{array}$ & AAATTCTCCGCCACATTGAG & 59 & $155-174$ & 11 & $\begin{array}{l}\text { basic leucine zipper } \\
\text { transcription factor-like } \\
\text { protein }\end{array}$ \\
\hline PIE125 & $\left(\mathrm{GGAAGC}_{3}\right.$ & $\begin{array}{c}\text { PET- } \\
\text { AATACAATCGCAGGAGGTG }\end{array}$ & CTAACCCATCGTTATGGAG & 57 & 146-162 & 6 & unknown \\
\hline PIE200 & $(\mathrm{CAA})_{s}$ & $\begin{array}{c}\text { 6.FAM- } \\
\text { ACAACATGGCCAAAACTGC }\end{array}$ & TCGATGATGTGGTTGTTGATG & 56 & $107-119$ & $\begin{array}{c}\text { not } \\
\text { assigned }\end{array}$ & $\begin{array}{c}\text { zinc finger a } 20 \text { and anl } \\
\text { domain-containing } \\
\text { stress-associated } \\
\text { protetin } 5 \text {-like }\end{array}$ \\
\hline VIT057 & $(\mathrm{AACTCG})_{3}$ & $\begin{array}{c}\text { VIC- } \\
\text { TCAGCAAATCCCAACTTGT }\end{array}$ & АСАСТTCGCTGTTCCTCGAT & 57 & 128-153 & 9 & $\begin{array}{l}\text { app } 2 \text { erf domam- } \\
\text { containing transcripion } \\
\text { factor }\end{array}$ \\
\hline VITo81 & $(\mathrm{CAT})_{4}$ & AATTCAAACCCAGCCAACTG & TCCTCTGGATGCTCCATCA & 56 & $108-112$ & $\underset{\substack{\text { not } \\
\text { assigned }}}{ }$ & proline-rich protein \\
\hline VIT107 & $(\mathrm{TA})_{3 \mathrm{~S}}$ & $\begin{array}{l}\text { NED. } \\
\text { TGATCACAGATTGGAGCTTAACA }\end{array}$ & CсCCCACTTAGGAAGGAAGC & 59 & 124-142 & 3 & $\begin{array}{l}\text { light-harvesting } \\
\text { complex proten Ihaca2 }\end{array}$ \\
\hline
\end{tabular}

\section{Data analyses}

The genetic variation parameters number of alleles per locus $\left(\mathrm{N}_{\mathrm{a}}\right)$, observed heterozygosity $\left(\mathrm{H}_{\mathrm{o}}\right)$, expected heterozygosity $\left(\mathrm{H}_{\mathrm{e}}\right)$ and the inbreeding coefficient $\left(\mathrm{F}_{15}\right)$ were determined in GenAlEx v. 6.502 (Peakall and Smouse, 2012). Genetic assignment analyses were conducted with the Bayesian approach implemented in the program STRUCTURE (Pritchard et al., 2000) to assign acorn and seedling samples to species and putative hybrids. For this purpose, selected seed parents were chosen as reference samples. Genetic assignment analyses were also conducted for the 12 seed parents together with 76 Q. rubra and 47 Q. ellipsoidalis adult trees from neighbouring stands of the same region as reference (Lind and Gailing, 2013). The admixture model with correlated allele frequencies and no prior species information was used. Five independent runs with a burn-in period of 30,000 iterations followed by $10^{6}$ iterations for each value of $\mathrm{K}$ ( $\mathrm{K}=1$ to 4 ) were applied to determine the value of K. According to Lind and Gailing (2013) hybrids and introgressive forms were defined as having a proportion of ancestry $<0.9$ in one of the two species (between 0.4 and 0.6 for hybrids, between 0.61 and 0.89 in one species for introgressive forms). Species were defined as having a proportion of ancestry of $\geq 0.9$ in one of the two species.

Survival was scored until May 6, 2016 and the frequency of species, hybrids and introgressive forms among surviving seedlings was calculated for different time points and compared between seedlings and non-germinated acorns. analyses. No obvious signs of infection were visible on the nongerminating seeds. Only 11 of the 23 markers tested, generated reproducible and easy-to-interpret allelic patterns in acorn samples which were further used for the comparison of genetic structures in seedlings and non-germinated acorns.

Table 2

Germination rate of Q. rubra, Q. ellipsoidalis and hybrids as determined by genetic assignment analysis of non-germinated acorns and seedlings

\begin{tabular}{|c|c|c|c|c|c|c|}
\hline & Q. rubra & Q. ellipsoidalis & $\begin{array}{l}\text { Q. rubra- } \\
\text { introgressive }\end{array}$ & $\begin{array}{l}\text { Q. ellipsoidalis- } \\
\text { introgressive }\end{array}$ & $\begin{array}{l}\mathrm{F}_{1^{-}} \\
\text {hybrid }\end{array}$ & overall \\
\hline \# Seedlings & 24 & 73 & 0 & 9 & 1 & 107 \\
\hline $\begin{array}{l}\text { \# Non-germinated } \\
\text { acorns }\end{array}$ & 49 & 8 & 21 & 14 & 9 & 101 \\
\hline \# Total & 73 & 81 & 21 & 23 & 10 & 208 \\
\hline Germination rate $(\%)$ & 32.9 & 90.1 & 0 & 39.1 & 10.0 & 51.4 \\
\hline
\end{tabular}

Genetic variation in non-germinated acorns $\left(\mathrm{H}_{\mathrm{o}}=0.465, \mathrm{H}_{\mathrm{e}}=\right.$ $0.464)$ and in seedlings $\left(H_{o}=0.440, H_{e}=0.467\right)$ was very similar (Supplementary Table 2). However, the level of genetic variation at PIE200 in seedlings $\left(\mathrm{H}_{\mathrm{e}}=0.067, \mathrm{H}_{\mathrm{o}}=0.066\right)$ and acorns $\left(\mathrm{H}_{\mathrm{e}}\right.$ $=0.547, H_{0}=0.488$ ) showed pronounced differences. Also, after genetic assignment (see below) Q. rubra seedlings $\left(H_{0}=0.100\right.$, $\mathrm{H}_{\mathrm{e}}=0.096$ ) showed a much lower variation than non-germinated Q. rubra acorns $\left(\mathrm{H}_{\mathrm{o}}=0.636, \mathrm{H}_{\mathrm{e}}=0.538\right)$ at PIE200 (Table 3). As result, genetic differentiation between $Q$. rubra seedling and acorn cohorts is high at PIE200 $\left(F_{S T}=0.128\right)$ as compared to the mean differentiation across markers $\left(F_{S T}=0.028\right)$. The variation in Q. rubra seedlings at PIE200 $\left(\mathrm{H}_{\mathrm{o}}=0.100, \mathrm{H}_{\mathrm{e}}=0.096\right)$ is somewhat higher than the variation observed in Q. ellipsoidalis seedlings $\left(\mathrm{H}_{\mathrm{o}}=0.058, \mathrm{H}_{\mathrm{e}}=0.057\right)$ and very similar as in nongerminated acorns of Q. ellipsoidalis $\left(H_{o}=0.111, H_{e}=0.105\right)$ (Supplementary Table 3). The low genetic variation at PIE200 in $Q$. rubra seedlings as compared to non-germinated $Q$. rubra acorns from the same sample could be a signature of positive selection and merits further analysis. PIE200 was annotated as A20/AN1-zinc-finger domain -containing-stress-associated protein 5-like (Lind-Riehl et al., 2014). The members of the A20/ AN1-zinc-finger domain -containing protein family are involved in abiotic stress responses in other species (Kang et al., 2011; Paul and Kumar, 2015).

\section{Results and Discussion}

The germination rate was comparatively low, only 107 out of 675 acorns (15.9\%) germinated (Table 2). For 101 of the nongerminated acorns and for all 107 seedlings, DNA of sufficient quality and quantity could be isolated for further DNA marker 
Table 3

Genetic variation of genetically assigned Q. rubra samples

\begin{tabular}{|c|c|c|c|c|c|c|}
\hline & Locus & $\mathrm{N}$ & $\mathrm{N}_{\mathrm{a}}$ & $\mathrm{H}_{\mathrm{o}}$ & $\mathrm{H}_{\mathrm{e}}$ & $\mathrm{F}$ \\
\hline \multirow{12}{*}{$\begin{array}{l}\text { Q. rubra } \\
\text { seedlings }\end{array}$} & FIR013 & 25 & 1 & 0.000 & 0.000 & - \\
\hline & FIR030 & 25 & 5 & 0.480 & 0.451 & -0.064 \\
\hline & FIR035 & 25 & 2 & 0.480 & 0.493 & 0.026 \\
\hline & FIR053 & 25 & 5 & 0.680 & 0.606 & -0.123 \\
\hline & FIR104 & 25 & 3 & 0.120 & 0.114 & -0.049 \\
\hline & PIE040 & 25 & 4 & 0.560 & 0.582 & 0.037 \\
\hline & PIE125 & 24 & 4 & 0.833 & 0.719 & -0.159 \\
\hline & PIE200 & 20 & 3 & 0.100 & 0.096 & -0.039 \\
\hline & VIT057 & 24 & 3 & 0.500 & 0.424 & -0.178 \\
\hline & VIT081 & 25 & 2 & 0.080 & 0.077 & -0.042 \\
\hline & VIT 107 & 24 & 4 & 0.708 & 0.553 & -0.281 \\
\hline & Mean & 24.3 & 3.3 & 0.413 & 0.374 & -0.087 \\
\hline \multirow{12}{*}{$\begin{array}{l}\text { Q. rubra } \\
\text { acorns }\end{array}$} & FIR013 & 48 & 2 & 0.021 & 0.021 & -0.011 \\
\hline & FIR030 & 39 & 6 & 0.462 & 0.526 & 0.123 \\
\hline & FIR035 & 48 & 2 & 0.396 & 0.364 & -0.086 \\
\hline & FIR053 & 45 & 4 & 0.756 & 0.628 & -0.203 \\
\hline & FIR104 & 45 & 4 & 0.222 & 0.204 & -0.087 \\
\hline & PIE040 & 37 & 4 & 0.541 & 0.627 & 0.138 \\
\hline & PIE 125 & 42 & 4 & 0.881 & 0.719 & -0.225 \\
\hline & PIE200 & 44 & 4 & 0.636 & 0.538 & -0.182 \\
\hline & VIT057 & 44 & 3 & 0.432 & 0.514 & 0.159 \\
\hline & VIT081 & 48 & 2 & 0.042 & 0.041 & -0.021 \\
\hline & VIT 107 & 36 & 4 & 0.639 & 0.601 & -0.064 \\
\hline & Mean & 43.3 & 3.5 & 0.457 & 0.435 & -0.042 \\
\hline
\end{tabular}

Proportion of ancestry of the seed parents (Supplementary Figure 2) and their offspring was strongly correlated ( $r=0.81, P$ $>0.001$ ). Genetic assignment analyses also revealed a much lower germination rate in Q. rubra than in Q. ellipsoidalis while the seedling mortality was higher in Q. ellipsoidalis (7 out of 73) than in Q. rubra (1 out of 24) (Figure 1, Table 2). A higher seedling mortality and slower growth of $Q$. ellipsoidalis seedlings was also found in a Q. rubra / Q. ellipsoidalis common garden seedling trial (Gailing, 2013). However, a lower germination rate of Q. rubra as compared to Q. ellipsoidalis acorns was not found in earlier studies (pers. observation; Gailing, 2013) and needs further validation under controlled growth chamber conditions. In the genetic admixture analysis, 73 out of the 107 seedlings were genetically assigned to $Q$. ellipsoidalis, 9 to $Q$. ellipsoidalis introgressive forms and only 24 to $Q$. rubra. Out of the 101 non-germinated acorns the majority was assigned to Q. rubra or Q. rubra introgressive forms $(49+21=70)$ and only 8 and 14 acorns were assigned to Q. ellipsoidalis and Q. ellipsoidalis introgressive forms, respectively (Figure 1, Table 2). The very low frequency of hybrids and introgressive forms in the seedling cohort (10 out of 107), but the assignment of nearly half (44 out of 101) of the acorns to $F_{1}$ hybrids $(n=9$ ) or introgressive forms (14 Q. rubra introgressive forms, 21 Q. ellipsoidalis introgressive forms) is a strong indication of early selection against hybrids and introgressive forms. Specifically, only one $F_{1}$ hybrid and no $Q$. rubra introgressive form were found in the seedling cohort. This early selection may be the result of genetic incompatibilities (intrinsic barriers) rather than of environmental selection (extrinsic barriers) (Rieseberg and Willis, 2007).

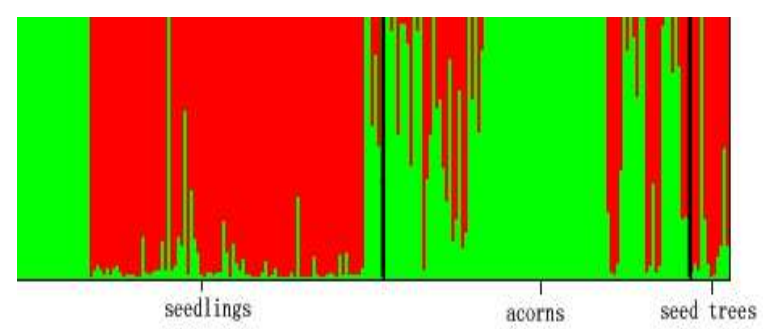

Figure 1

Genetic assignment analysis of seedlings and non-germinated acorns in STRUCTURE. Green: Q. rubra. Red: Q. ellipsoidalis.

These results are in accordance with a low number of $F_{1}$ hybrids and introgressive forms in the sympatric adult population from which the acorns were collected (4.2\% $\mathrm{F}_{1}$ hybrids, $5.2 \% \mathrm{Q}$. rubra introgressive forms, 7.3\% Q. ellipsoidalis introgressive forms) using the same program settings and definitions of hybrids/ introgressive forms (Khodwekar and Gailing, 2017).

However, the frequency of $F_{1}$ hybrids and introgressive forms varies among regions where both species grow in close proximity on different contrasting soil types (Lind-Riehl et al., 2014; Lind-Riehl and Gailing, 2017). For example, in some regions the frequency of $F_{1}$ hybrids among adult trees was as high as $10 \%$ and reached $23 \%$ for introgressive forms (Lind-Riehl and Gailing, 2017) suggesting less pronounced early postzygotic selection and possibly a dependency of selection at later seedling stages on soil and other environmental factors. Also, the restriction of oak hybrids and introgressive forms in sympatric stands to contact zones between species in different microenvironments for both American red oak (Owusu et al., 2015; Khodwekar and Gailing, 2017) and European white oak species (Curtu et al., 2007; De Heredia et al., 2009) suggests environment-driven selection against hybrids in parental environments. In line with these results Dodd and Afzal-Rafii (2004) found that the proportion of hybrids and introgressive forms in Californian red oaks was correlated with climate variables and to a lesser degree with geographic distance. Other indirect evidence for postzygotic selection against hybrids originated from comparisons of genetic assignment analyses of adult trees and paternity analyses in single tree pedigree of the same sympatric stands. Thus, the proportion of hybrids and introgressive forms in a sympatric Q. petraea, Q. robur, Quercus pubescens Willd. and Quercus frainetto Ten. European white oak stand was considerably lower in the adult tree generation (20.1 \%) (Curtu et al., 2007) than in the seeds as inferred from paternity analyses (35.9\%) (Curtu et al., 2009). 


\section{Conclusions}

To our knowledge, this is the first study in oaks providing direct evidence for early selection against hybrids by comparing their frequency in seedlings and non-germinated acorns from the same random sample. Also, the pronounced genetic differentiation between seedlings and non-germinated acorns of $Q$. rub$r a$ and the very low variation in the seedlings at one marker (PIE200) suggests positive selection which merits further analyses. Finally, reciprocal transplant experiments of species and hybrids in sympatric stands with a higher number of hybrids are needed to test for environmental selection against hybrids at later seedling stages.

\section{Acknowledgements}

Funding was provided by the Mclntire Stennis fund (USDANIFA \# 1001471). Ruhua Zhang was funded by a scholarship of the Education Department of Shandong Province.

\section{References}

Abadie P, G Roussel, B Dencausse, C Bonnet, E Bertocchi, JM Louvet, A Kremer and P Garnier-Gere (2012) Strength, diversity and plasticity of postmating reproductive barriers between two hybridizing oak species (Quercus robur L. and Quercus petraea (Matt) Liebl.). Journal of Evolutionary Biology 25:157 173. https://doi.org/10.1111/j.1420-9101.2011.02414.x

Abraham ST, DN Zaya, WD Koenig and MV Ashley (2011) Interspecific and intraspecific pollination patterns of valley oak, Quercus lobata, in a mixed stand in coastal central California. International Journal of Plant Sciences 172:691699. https://doi.org/10.1086/659646

Abrams MD (1990) Adaptations and responses to drought in Quercus species of North America. Tree Physiology 7:227-238. https://doi.org/10.1093/treephys/7.1-2-3-4.227

Abrams MD (1992) Fire and the development of oak forests in eastern North America, oak distribution reflects a variety of ecological paths and disturbance conditions. Bioscience 42:346-353. https://doi.org/10.2307/1311781

Cottam WP, JM Tucker and FS Santamour Jr. (1982) Oak hybridization at the University of Utah. State Arboretum of Utah, University of Utah.

Curtu AL, O Gailing and R Finkeldey (2007) Evidence for hybridization and introgression within a species-rich oak (Quercus spp.) community. BMC Evolutionary Biology 7:218. Artn 218. https://doi.org/10.1186/1471-2148-7-218

Curtu AL, O Gailing and R Finkeldey (2009) Patterns of contemporary hybridization inferred from paternity analysis in a four-oak-species forest. BMC Evolutionary Biology 9:284. Artn 284. https://doi.org/10.1186/1471-2148-9-284

de Heredia UL, M Valbuena-Carabana, M Cordoba and L Gil (2009) Variation components in leaf morphology of recruits of two hybridising oaks $Q$. petraea (Matt.) Liebl. and Q. pyrenaica Willd. at small spatial scale. European Journal of Forest Research 128:543-554. https://doi.org/10.1007/s10342-009-0302-6

Dodd RS, and Z Afzal-Rafii (2004) Selection and dispersal in a multispecies oak hybrid zone. Evolution 58:261-269. https://doi.org/10.1111/j.0014-3820.2004.tb01643.x

Durand J, C Bodénès, E Chancerel, J-M Frigero, GG Vendramin, F Sebastiani, A Buonamici, O Gailing, H-P Koelewijn, F Villani, C Mattioni, M Cherubini, PG Goicoechea, A Herran, Z Ikaran, C Cabane, S Ueno, A de Daruvar, A Kremer and C Plomion (2010) A fast and cost-effective approach to develop and map EST-SSR markers: oak as a case study. BMC Genomics 11:570.

https://doi.org/10.1186/1471-2164-11-570

Gailing O (2013) Differences in growth, survival and phenology in Quercus rubra and Q. ellipsoidalis seedlings. Dendrobiology 70:71-79. https://doi.org/10.12657/denbio.070.008

Gailing O, S Kostick, O Caré and S Khodwekar (2018) Leaf morphological and genetic variation between Quercus rubra and Quercus ellipsoidalis: comparison of sympatric and parapatric populations. Annals of Forest Research 61:8194. https://doi.org/10.15287/afr.2018.1020

Kang MY, M Fokar, H Abdelmageed and RD Allen (2011) Arabidopsis SAP5 functions as a positive regulator of stress responses and exhibits $E 3$ ubiquitin ligase activity. Plant Molecular Biology 75:451-466. https://doi.org/10.1007/s11103-011-9748-2

Khodwekar S, and O Gailing (2017) Evidence for environment-dependent introgression of adaptive genes between two red oak species with different drought adaptations. American Journal of Botany 104:1088-1098. https://doi.org/10.3732/ajb.1700060

Kleinschmit J, and JRG Kleinschmit (2000) Quercus robur - Q. petraea: a critical review of the species concept. Glasnik Za sumske Pokuse 37:441-452.

Lepais O, G Roussel, F Hubert, A Kremer and S Gerber (2013) Strength and variability of postmating reproductive isolating barriers between four European white oak species. Tree Genetics \& Genomes 9:841-853. https://doi.org/10.1007/s11295-013-0602-3

Lexer C, A Kremer and RJ Petit (2006) Shared alleles in sympatric oaks: recurrent gene flow is a more parsimonious explanation than ancestral polymorphism. Molecular Ecology 15:2007-2012. https://doi.org/10.1111/j.1365-294x.2006.02896.x

Lind-Riehl J, and O Gailing (2017) Adaptive variation and introgression of a CONSTANS-like gene in North American red oaks. Forests 8:3. https://doi.org/10.3390/f8010003

Lind-Riehl JF, AR Sullivan and O Gailing (2014) Evidence for selection on a CONSTANS-like gene between two red oak species. Annals of Botany 113:967975. https://doi.org/10.1093/aob/mcu019

Lind J, and O Gailing (2013) Genetic structure of Quercus rubra L. and Q. ellipsoidalis E. J. Hill populations at gene-based EST-SSR and nuclear SSR markers. Tree Genetics \& Genomes 9:707-722. https://doi.org/10.1007/s11295-012-0586-4

Olrik DC, and ED Kjaer (2007) The reproductive success of a Quercus petraea $\times$ Q robur F1-hybrid in back-crossing situations. Annals of Forest Science 64:3745. https://doi.org/10.1051/forest:2006086

Owusu SA, AR Sullivan, JA Weber, AL Hipp and O Gailing (2015) Taxonomic relationships and gene flow in four North American Quercus species. Systematic Botany 40:510. https://doi.org/10.1600/036364415x688754

Paul A, and S Kumar (2015) An A20/AN1-zinc-finger domain containing protein gene in tea is differentially expressed during winter dormancy and in response to abiotic stress and plant growth regulators. Plant Gene 1:1-7. https://doi.org/10.1016/j.plgene.2014.12.003

Peakall R, and PE Smouse (2012) GenAIEx 6.5: genetic analysis in Excel. Population genetic software for teaching and research-an update. Bioinformatics 28:2537-2539. https://doi.org/10.1093/bioinformatics/bts460

Pritchard JK, M Stephens and P Donnelly (2000) Inference of population structure using multilocus genotype data. Genetics 155:945-959.

Rieseberg LH, and JH Willis (2007) Plant Speciation. Science 317:910-914. https://doi.org/10.1126/science.1137729

Sander IL (1990) Quercus rubra L., pp. 727-733 in Silvics of North America. U.S. Department of Agriculture, Forest Service, Washington DC.

Steinhoff S (1993) Results of species hybridization with Quercus robur L. and Quercus petraea (Matt) Liebl. Annales des Sciences Forestières 50:137s-143s. https://doi.org/10.1051/forest:19930713

Zhang R, AL Hipp and O Gailing (2015) Sharing of chloroplast haplotypes among red oak species suggests interspecific gene flow between neighboring populations. Botany 93:691-700. https://doi.org/10.1139/cjb-2014-0261 